\title{
Molecular Cloning of African Swine Fever Virus DNA
}

\author{
V. Ley, J.M. Almendra, P. Carbonero, A. Beloso, E. Viñuela, \\ A. Talavera
}

\begin{abstract}
African swine fever virus DNA (about $170 \mathrm{kbp}$ ) was cleaved with the restriction endonuclease EroRI and most of the resulting 31 fragments were cloned in either the phage vector $\lambda$ WES. $A B$ or the plasmid pBR325. Three fragments were not cloned in those vectors, the largest fragment EcoRI- $\Lambda(21.2 \mathrm{kbp})$ and the two crosslinked terminal fragments, EcoRI-K' and D'. Endonuclease Sul cut fragment EcoRI-A into three pieces which were cloned in plasmid pBR322. The two terminal EcoRI fragments were cloned after removal of the crosslinks with nuclease S1 and addition of EcoRI linkers to the fragment ends. The complete library of the cloned fragments accounted for about $98 \%$ of ASF virus genome, the missing sequences being those removed by the nuclease S1 in the process of cloning the terminal fragments.
\end{abstract}

\section{INTRODUCTION}

African swine fever (ASF) is an important disease of domestic pigs (Hess, 1971, 1981), produced by an icosahedral cytoplasmic deoxyvirus of about $200 \mathrm{~nm}$ (Breese and DeBoer, 1966). The genome of ASF virus is a linear duplex DNA with a molar mass of about $100 \times 10^{6 \mathrm{~g}} \mathrm{~g} \mathrm{~mol}^{-1}$ (Enjuanes et al., 1976) and covalently closed ends (Ortín et al., 1979), similar to those present in poxvirus DNA (Geshelin and Berns, 1974; Baroudy et al, 1982).

The large size of ASF virus DNA and the low virus production in cell culture have made it difficult to study ASF virus at the molecular level. The availability of clones with defined DNA fragments would be useful for mapping viral transcripts and their translation products, sequencing regions of the viral genome, and for the study of gene expression.
This paper shows the molecular cloning of a collection of restriction EcoRI and SalI fragments of ASF virus DNA, which account for about $98 \%$ of the viral genome.

\section{MATERIALS AND METHODS}

Viruses and cells. ASF virus, adapted to grow in VERO cells, was described by Almendral et al. (1984).

DNAs. ASF virus DNA was isolated as described by Almendral el al. (1984).

Bacteriophage $\lambda$ WES. $\lambda B$ and phage recombinants were precipitated from Escherichia coli lysates as described (Yamamoto et $a l, 1970$ ) and purified by either CsCl centrifugation or chromatography in Biogel A5M (Sain and Erdei, 1981).

Plasmids pBR322 and pBR325, with or without $\mathrm{ASF}$ virus DNA restriction fragments, were prepared by standard techniques (Maniatis et $a l$, , 1982). DNAs were stored in TE buffer (10 $\mathrm{m} M$ Tris- $\mathrm{HCl}, \mathrm{pH}$ $8,1 \mathrm{~m} M$ EDTA).

$D N A$ restriction, electrophoresis, and hybridization. Restriction enzyme digests, agarose electrophoresis, blotting, and hybridization were carried out as described by Maniatis et al. (1982).

Cloning of internal restriction fragments. 
(1) Cloning in $\lambda$ WES. $\lambda B . E c o$ RI restriction fragments were cloned in $\lambda$ WES $\lambda B$ as described (Hohn and Murray, 1977; Hohn, 1979).

(2) Cloning in pBR325. Ligation of ASF virus DNA EcoRI fragments, recovered from agarose gels, to pBR325 cut with EcoRI was done by standard techniques (Maniatis et al., 1982). The ligation products were used to transform E. coli HB101 (Mandel and Higa, 1970) and the bacteria plated on $\mathrm{L}$ agar ( $\mathrm{L}$ medium with $1.6 \%$ agar) containing ampicillin $(50 \mu \mathrm{g} / \mathrm{ml})$ and crystal violet $(2 \mu \mathrm{g} / \mathrm{ml})$. The dye accumulates in chloramphenicol-resistant bacteria, giving place to blue colonies, whereas bacteria carrying recombinant pBR325 produce white colonies (Proctor and Rownd, 1982). The latter were tested for chloramphenicol sensitivity and by hybridization to ASF virus $\left[{ }^{32} \mathrm{P}\right] \mathrm{DNA}$ (Grünstein and Hogness, 1975). The positive colonies were recovered from the master plate and used to prepare recombinant plasmids.

(3) Cloning in pBR322. SalI and EcoRISalI restriction fragments were cloned in pBR322 treated with the corresponding enzymes. After transformation, the recombinants were tested for tetracycline resistance in the absence of $\mathrm{Mg}^{2+}$ and by hybridization to $\mathrm{ASF}$ virus $\left[{ }^{32} \mathrm{P}\right] \mathrm{DNA}$ (Maniatis et al., 1982).

Isolation and cloning of terminal EcoRI restriction fragments. Terminal EcoRI fragments were isolated, free of internal fragments, by using the snapback-S1 technique of Jaureguiberry (1977) and Wittek et al. (1977). In some experiments, the terminal fragments were separated from each other by centrifugation of the nuclease digestion mixture in a $5-20 \% \mathrm{NaCl}$ gradient in a Beckman SW40 rotor at $30,000 \mathrm{rpm}$ for $6 \mathrm{hr}$ at $4^{\circ}$ (Liu et al., 1980). The fractions containing each terminal fragment were pooled and the DNA was precipitated with ethanol. The precipitate was dissolved in S1 buffer and treated with S1 nuclease. The blunt-ended fragments, obtained by either method, were added to EcoRI linkers in the presence of $0.5 \mathrm{~m} M$ ATP (Ferretti and Sgaramella, 1981) and T4 DNA ligase. After EcoRI treatment, vector DNA (pBR325 or $\lambda$ WES. $\lambda \mathrm{B}$ arms) was added as a carrier and the mixture was passed through a Ultrogel AcA 34 column (Anderson, 1981). The DNA in the void volume was treated with T4 DNA ligase in the presence of 1 $\mathrm{m} M$ ATP, and the recombinant molecules were packaged into lambda particles or used to transform $E$. coli HB101.

Recombinant nomenclature. Recombinants of pBR322 or pBR325 and a specific restriction fragment were named $\mathrm{p} 2$ (for pBR322) or p5 (for pBR325), followed by an abbreviation for the restriction enzyme (R, EcoRI; S, Sal I), a letter designating the fragment and the isolation number of the recombinant. Recombinants of lambda DNA and a restriction fragment were named as above by substituting $\mathrm{L}$ for $\mathrm{p} 2$ or $\mathrm{p} 5$.

Recombinants with fragments produced by two nucleases were designated as above, by taking into account the orientation of the restriction fragment map (Almendral et al, 1984), indicating, first, the site cut to the left and then the one cut to the right, separated both by a tilted bar. Thus, for example, p2SD/RC'7 (Fig. 7).

Materials. Restriction enzymes, E. coli DNA polymerase and T4 DNA ligase were purchased from New England Biolabs and nuclease S1 from Sigma Chemical Company. Spectinomycin was a gift from Upjohn Diagnostics and the other antibiotics were from Sigma Chemical Company. Agarose (type II) was from Sigma Chemical Company, nitrocellulose membranes (HAW 304FO) from Millipore, Ultrogel AcA34 from LKB, and Biogel A5m from BioRad. Putrescine and spermidine were purchased from Sigma Chemical Company and $\left[\gamma^{32} \mathrm{P}\right] \mathrm{ATP},\left[\alpha^{-32} \mathrm{P}\right] \mathrm{dATP}$, and $[\alpha-$ $\left.{ }^{32} \mathrm{P}\right] \mathrm{dTTP}$ from the Radiochemical Center, Amersham.

\section{RESULTS}

\section{Random Cloning of EcoRI Fragments}

Cleavage of ASF virus DNA with EcoRI produces 31 fragments (Almendral et al, 1984). From 259 recombinants obtained, 254 contained one single fragment, the largest one being EcoRI-C (11.5 kbp) and the smallest EcoRI-K ( $4.8 \mathrm{kbp})$. Fragments EcoRI-L, N, P, R, and U, with sizes below 
$4.8 \mathrm{kbp}$, were obtained in recombinants carrying more than one viral fragment, Since fragments EcoRI-D' (10.7 kbp) and $\mathrm{K}^{\prime}(4.8 \mathrm{kbp})$ are terminal (Almendral et $a l ., 1984)$, recombinants with either one of those fragments were not obtained. The most frequent fragment cloned in $\lambda$ WES. $\lambda B$ was EcoRI-F (108 clones), which has a size of $8.4 \mathrm{kbp}$. Figure 1 shows the characterization of the recombinants carrying single EcoRI fragments.

To distinguish the recombinants with fragments that, being different, had the same electrophoretic mobility, [ $\left.{ }^{32} \mathrm{P}\right] \mathrm{DNA}$ from one of these recombinants was hybridized to the DNA restriction fragments from each of the other recombinants. The clones giving a positive signal carried one of the two fragments and the negative ones the second fragment. This was confirmed by hybridization of $\left[{ }^{32} \mathrm{P}\right] \mathrm{DNA}$ from one negative recombinant with the DNA restriction fragments from each of the other clones (data not shown).

Figure $7 \mathrm{~b}$ shows the map position (Almendral et al., 1984) of the 16 EcoRI fragments cloned in $\lambda$ WES. $\lambda \mathrm{B}$ in the experiment indicated above, and that of the terminal EcoRI-D', separately cloned in $\lambda$ WES. $\lambda \mathrm{B}$ (see below).

\section{Cloming of Isolated EcoRI Fragments}

Internal EcoRI fragments not cloned as single inserts in phage $\lambda$ WES. $\lambda \mathrm{B}$ were electroeluted from agarose gels, incubated with EcoRI linearized pBR325 and DNA ligase and the reaction products were used

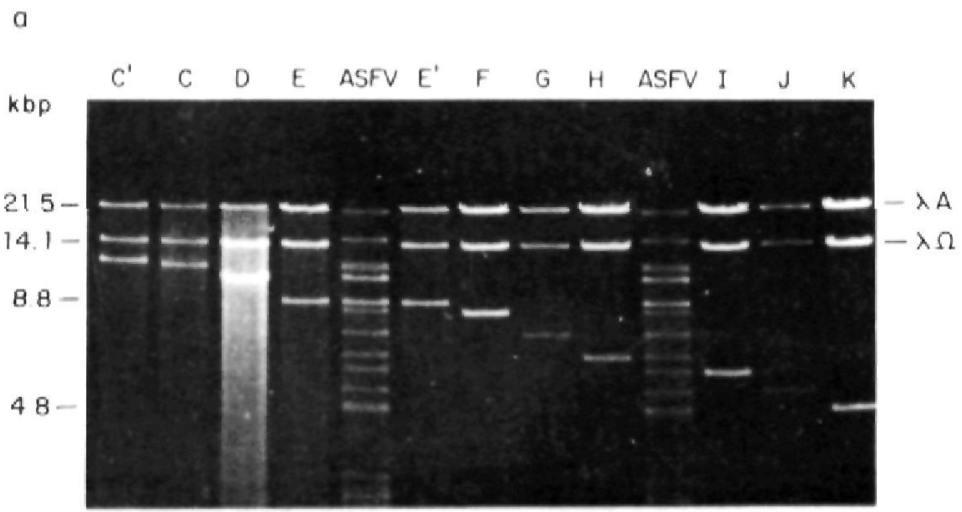

b

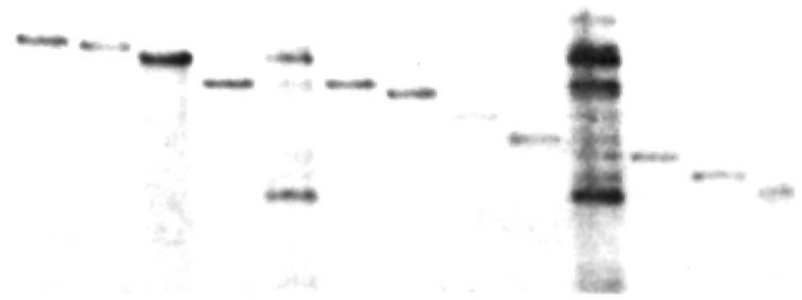

FIG. 1. Characterization of EcoRI fragments cloned in $\lambda$ WES. $\lambda B$. (a) Phage recombinants carrying single EcoRI fragments were purified and the DNA extracted and digested with EcoRI. The digests were subjected to electrophoresis in a $0.5 \%$ agarose gel. (b) The DNA was transferred from the gel shown in (a) to a nitrocellulose sheet and hybridized to ASF virus [ ${ }^{32}$ PJDNA. Lanes labeled ASFV were loaded with an EcoRI digest of ASF virus DNA. Other lanes are labeled with the letter designating the cloned EcoRI fragment. $\lambda A$ and $\lambda \Omega$ indicate the two terminal EcoRI fragments of $\lambda$ WES.AB DNA. 
to transform $E$. coli HB101. Figure 2 shows that all the expected fragments, except fragment EcoRI-A, were found in the recombinants.

Figure 7c shows the map position of the EcoRI fragments cloned in pBR325 and the terminal fragment EcoRI-K', separately cloned in pBR325 (see below).

\section{Cloming of Fragment EcoRI-A}

Two SalI sites divide fragment EcoRIA in three segments, EcoRI-A/Sal I-C (13.1 kbp), Sal I-I' (5.5 kbp), and SalI-B/EcoRIA (3.0 kbp) (Almendral et $a l, 1984)$ (see Figs. 7a, d, e).
Fragment SalI-I' was obtained after cloning a mixture of SalI fragments of ASF virus DNA into plasmid pBR322 (Fig. 3). In this experiment we also obtained, among others, fragment SalI-B (25 kbp), which contained the segment SalI-B/EcoRI-A (Figs. 3 and 7 d, e).

To clone fragment EcoRI-A/SalI-C, fragment $S a l \mathrm{I}-\mathrm{C}$, contaminated with fragments $A$ to $D$ was recovered from an agarose gel. The mixture was treated with EcoRI and the products ligated to a fragment of plasmid pBR322, flanked by the EcoRI and SalI cohesive sites. After transformation, we obtained, among others, the fragments EcoRI-A/SalI-C and SalI-B/

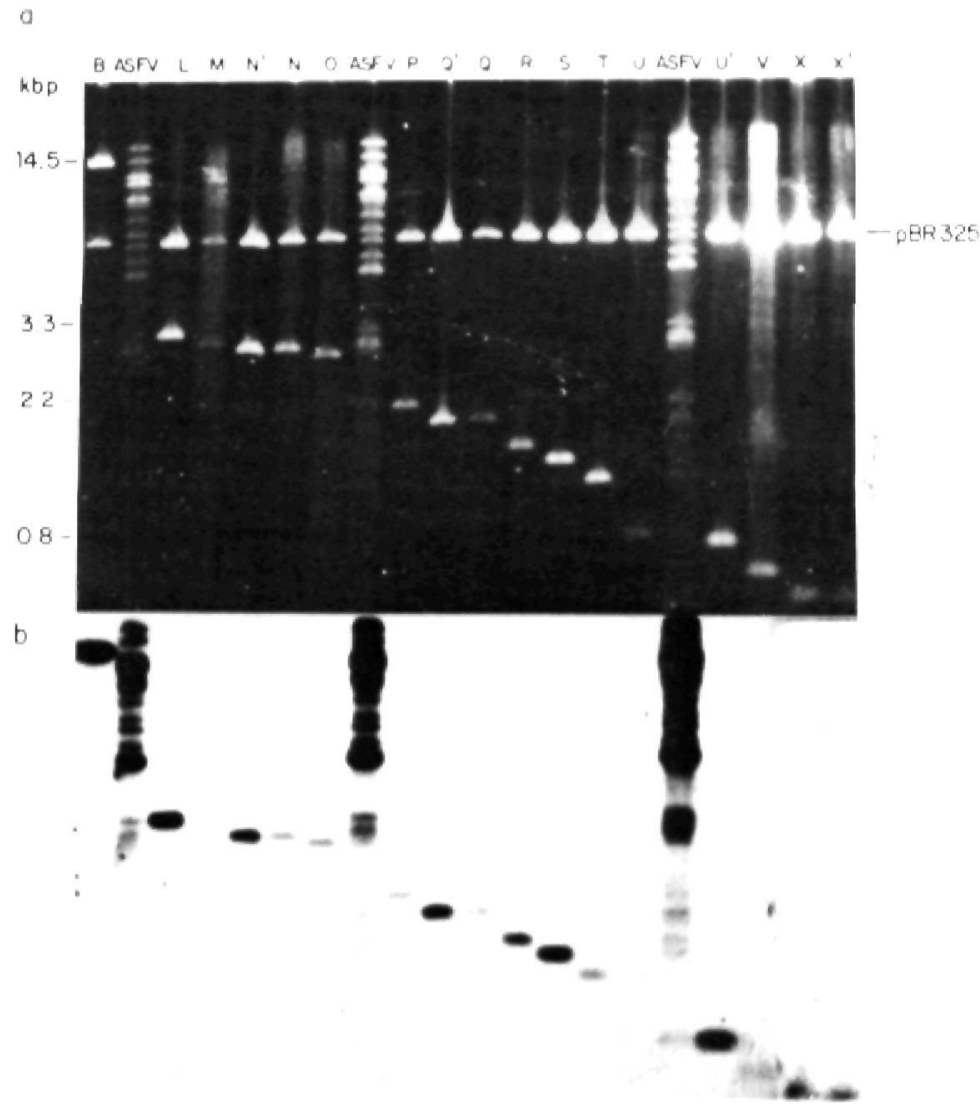

FIG. 2. Characterization of EicoRI fragments cloned in pBR325. (a) Plasmid recombinants carrying each of the cloned fragments were digested with EcoRI and subjected to electrophoresis. (b) The DNA was transferred from the gel shown in (a) to a nitrocellulose sheet and hybridized to ASF virus $\left[{ }^{32}\right.$ P]DNA. Lanes labeled ASFV were loaded with an EcoRI digest of ASF virus DNA. Other lanes are labeled with the letter designating the cloned EcoRI fragment. 


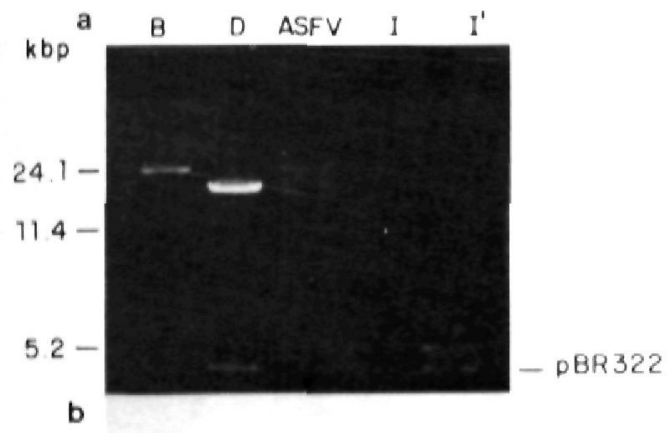

FIG. 3. Characterization of Sal I fragments cloned in pBR322. (a) Recombinants carrying different Sall fragments were digested with nuclease SalI and the reaction products electrophoresed in parallel with a Sal digest of ASF virus DNA. (b) The DNA was transferred from the gel shown in (a) to a nitrocellulose sheet and hybridized to ASF virus [ ${ }^{32} \mathrm{P}$ JDNA. The lane Iabeled ASFV was loaded with a SalI digest of ASF virus DNA. Other lanes are labeled with the letter designating the cloned SalI fragments.
EcoRI-A (Figs, 4 and 7e) which, together with fragment SalI-I' (Fig. 3), covered the whole length of fragment EcoRI-A.

\section{Cloming of the Terminal Fragments EcoRI $D^{\prime}$ and $K^{\prime}$}

Fragments EcoRI D' (10.7 kbp) and $\mathrm{K}^{\prime}$ $(4.8 \mathrm{kbp})$, obtained by the snapback-S1 technique, were inserted into plasmid pBR325 after addition of EcoRI linkers and the products used to transform $E$. coli HB101. Figure 5a shows that all the rewminamos unamer in this experiment contained viral inserts shorter than either terminal fragment. The recombinant with the largest insert (plasmid p5RD'76) had a 4.4-kbp-long viral fragment (Fig. 5a) and hybridized to both terminal fragments EcoRI-D' and K' (Fig. 5a). This indicated that the recombinant contained, at least in part, the 2.1-kbp-long inverted terminal repetition present in ASF virus DNA (Sogo et al, 1984). The sensitivity of either p5RD'76 plasmid or the other recombinants to PvuI endonuclease indicated that the inserts belonged to fragment EcoRI-D', since EcoRI-K' has no Pvul site (Almendral et $a l, 1984$ ) (data not shown).

The terminal inverted repeat cloned in

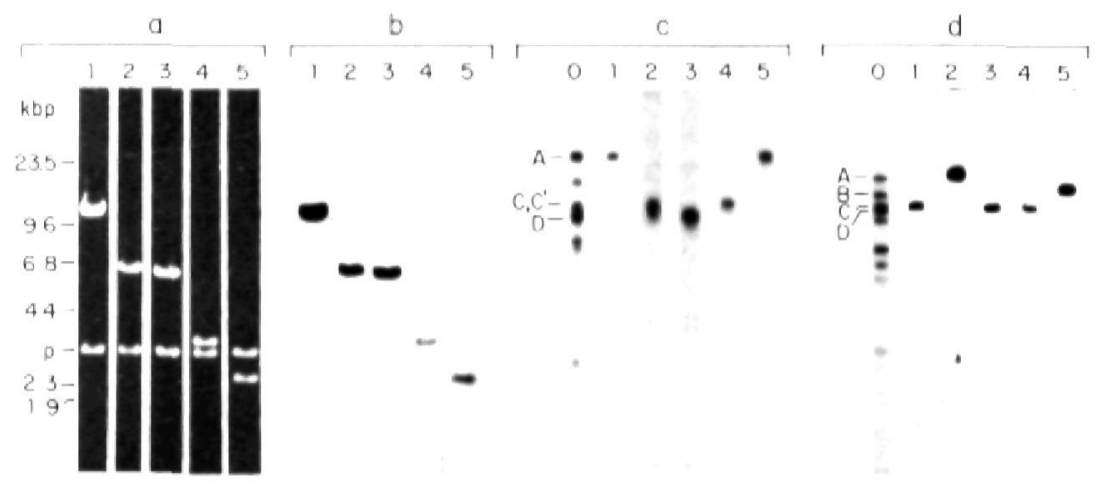

FIG. 4. Characterization of recombinants containing Sal / EcoRI double restriction fragments. (a) pBR322 recombinants were digested with both. Sal I and EcoRI and the reaction products subjected to agarose electrophoresis, in parallel with HindIII fragments of lambda DNA as size markers; lane 1, recombinant p2RA/SC3; lane 2, p2RC/SA5; lane 3, p2RD/SD4; lane 4, p2SD/RC7; lane 5, p2SB/RA1, (b) The INNA was transferred from the gel shown in (a) to a nitrocellulose sheet and hybridized to ASF vìrus [ ${ }^{32}$ P]DNA; lanes 1-5 as in (a). (c) and (d) Nitrocellulose strips with immobilized EcoRI or SalI fragments, respectively, of ASF virus DNA were hybridized to $\left[{ }^{32}\right.$ P]DNA from each recombinant (lanes $1-5$ ) or from $\mathrm{ASF}$ virus (lane 0). 
a

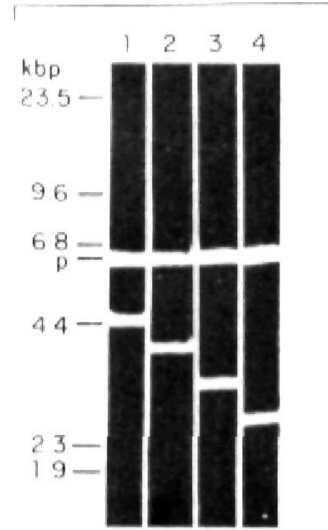

b

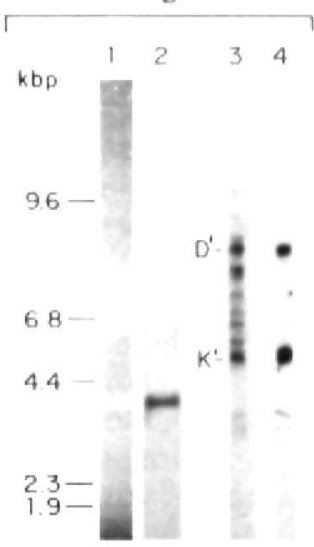

$\mathrm{C}$

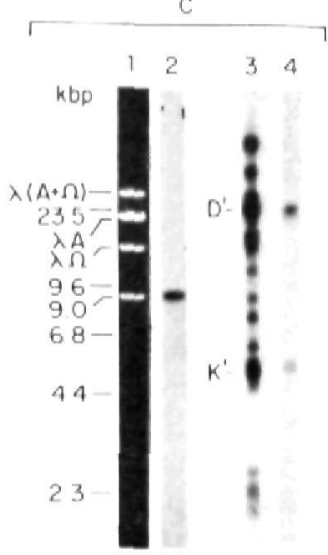

FIG. 5. Characterization of recombinants carrying terminal EcoRI fragments. (a) pBR325 recombinants with terminal EcoRI fragments were digested with EcoRI and the reaction products electrophoresed in parallel with HindIII fragments of lambda DNA. Lanes 1-4, recombinants p5RD'76, p5RD'61, p5RD'48, and p5RD'47, respectively; lane 5, immobilized EcoRI fragments of ASF virus DNA hybridized to ASF virus $\left[{ }^{32} \mathrm{P}\right]$ DNA; lane 6 , immobilized EcoRI fragments of ASF virus DNA hybridized to p5RD76 [ ${ }^{32}$ P|DNA. (b) Lane 1, recombinant p5RK'1 was digested with EcoRI and the reaction products were electrophoresed in parallel with HindIII fragments of lambda DNA; lane 2, DNA was transferred from the gel shown in lane 1 to a nitrocellulose sheet and hybridized to ASF virus $\left[{ }^{32} \mathrm{P}\right] \mathrm{DNA}$; lane 3 , as lane a5; lane 4, immobilized EcoRI fragments of ASF virus DNA hybridized to p5RK'1 [ ${ }^{32}$ P]DNA. (c) Lane 1, recombinant LRD'16 was digested with EcoRI and the reaction products were electrophoresed in parallel with HindIII fragments of lambda DNA; lane 2, DNA was transferred from the gel shown in lane 1 to a nitrocellulose sheet and hybridized to ASF virus $\left[{ }^{32} \mathrm{P}\right] \mathrm{DNA}$; lane 3, as lane a5; lane 4, immobilized EcoRI fragments of ASF virus DNA hybridized to LRD'16 [ $\left.{ }^{32} \mathrm{P}\right] \mathrm{DNA}$. p Indicates plasmid pBR325 and $\lambda \mathrm{A}, \lambda \Omega$, and $\lambda(\mathrm{A}+\Omega)$ the terminal EcoRI fragments, alone and linked through the cohesive ends of lambda DNA.

recombinant $\mathrm{p} 5 \mathrm{RD} \mathrm{D}^{\prime} 76$ was used as a probe to select a new set of recombinants containing terminal fragments. One recombinant, p5RK'1, contained a 3.8-kbp-long insert (Fig. 5b) that lacked PvuI sites indicating that it was a part of fragment EcoRI-K' which had lost about $1 \mathrm{kbp}$ by the $\mathrm{S} 1$ treatment involved in the cloning process (data not shown).

To isolate an EcoRI-D' subfragment as complete as possible, the terminal crosslinks of ASF virus DNA were removed without the snapback renaturation step. A mixture of EcoRI fragments (A to $\mathrm{D}^{\prime}$ ), isolated in a $\mathrm{NaCl}$ gradient, was treated with nuclease $\mathrm{S} 1$ and the blunt-ended products were cloned in $\lambda$ WES. $\lambda B$ after addition of EcoRI linkers. The largest recombinant (LRD'16) that hybridized with p5RD'76 contained a 9.0 -kbp-long insert, shorter than fragment EcoRI-D' (10.7 kbp). Figure 5 e shows that LRD'16 hybridized with ASF virus $\left[{ }^{32} \mathrm{P}\right] \mathrm{DNA}$ and the $\left[{ }^{32} \mathrm{P} \mid \mathrm{DNA}\right.$ from the recombinant hybridized with fragments EcoRI-D' and K'.

To determine the extent of the deletions at either end of the cloned EcoRI-D' fragment in recombinant LRD'16, we mapped the SmaI sites in LRD'16, knowing that SmaI cleaves EcoRI-D' (10.7 kbp) in two 7.0- and 3.7-kbp-long segments (Almendral et al., 1984), the left lambda arm in two 19.7- and 1.9-kbp-long segments and the right arm in two other segments with a length of 8.2 and $5.9 \mathrm{kbp}$ (Daniels and Blattner, 1982). Figure 6 shows that digestion of LRD'16 DNA with SmaI produced four fragments. Two, 19.7 and $5.9 \mathrm{kbp}$ long, derived from the ends of the molecule, respectively. A third fragment of $11.6 \mathrm{kbp}$ contained the $8.2-\mathrm{kbp}$-long fragment from the right arm of $\lambda$ WES, $\lambda B$ DNA plus a $3.4-$ kbp-long piece from the insert. The fourth fragment of $7.5 \mathrm{kbp}$ was the sum of the 


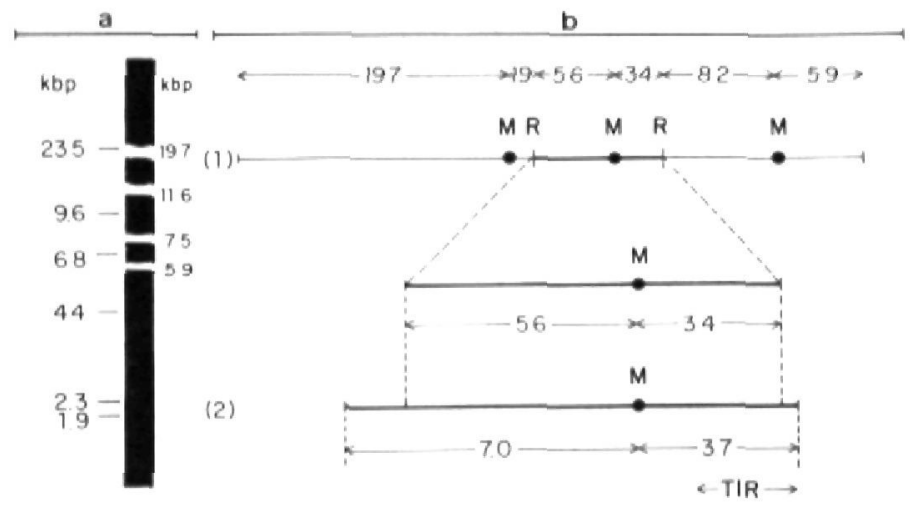

FIG. 6. Determination of the deletion extents of recombinant LRD'16 carrying the terminal fragment EcoRI-D'. (a) Recombinant LRD'16 DNA was digested with SmaI and electrophoresed in parallel with HindIII fragments of lambda DNA. (b) DNA map of recombinant LRD'16, showing the EcoRI (R) and SmaI (M) sites (1), compared with the map of the terminal fragment EcoRI-D' (2) as determined by Almendral et al. (1984). TIR indicates the 2.1-kbp-long terminal inverted repetition of ASF virus DNA (Sogo et ah, 1984).

1.9-kbp-long fragment, derived from the left arm of $\lambda$ WES. $\lambda$ B DNA, and a $5.6-\mathrm{kbp}^{-}$ long piece from the insert. These results led to the conclusion that fragment EcoRI$\mathrm{D}^{\prime}$ in the recombinant LRD'16 lacked 1.4 and $0.3 \mathrm{kbp}$ in the left and right ends, respectively. A similar analysis done with nuclease PvuI and $K p m I$ led to the same conclusion (data not shown).

\section{DISCUSSION}

A library of clones of all the EcoRI fragments of ASF virus DNA, except fragment A, has been obtained. Fragment EcoRI-A $(21.2 \mathrm{kbp})$ was cloned in three pieces, obtained by digestion of EcoRI-A with nuclease SalI (Figs. 7d and e).

In total, about $98 \%$ of the ASF virus

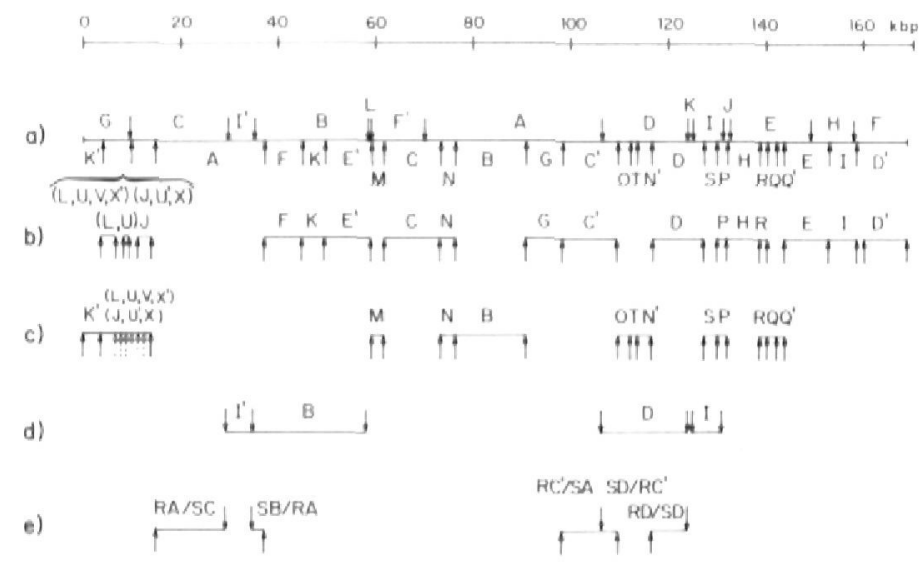

FIG. 7. Map location of cloned fragments of ASF virus DNA. (a) Restriction site map of ASF virus DNA showing the EcoRI ( $($ ) and SalI (t) restriction sites (Almendral et al., 1983); (b) location of the EcoRI fragments cloned in $\lambda$ WES, $\lambda B$; (c) location of the EcoRI fragments cloned in pBR325; (d) location of the SalI fragments cloned in pBR322; (e) location of the SalI/EcoRI fragments cloned in pBR322. 
DNA sequences (Almendral et al, 1984) have been inserted into either phage or plasmid vectors. The missing sequences were deletions produced by nuclease S1 in the process of cloning the terminal fragments; about $1 \mathrm{kbp}$ in fragment EcoRI-K' $(4.8 \mathrm{kbp})$ and $1.7 \mathrm{kbp}$ in EcoRI-D' $(10.7 \mathrm{kbp})$. The cloning of the terminal fragments of vaccinia virus DNA by similar methods. but using vaccinia endonuclease instead nuclease S1, produced deletions of about 50 bp near the crosslinks (Wittek and Moss, 1980; Baroudy et al., 1982). The large difference of the deletions produced in each case was probably due to either the different nucleases used to remove the crosslinks or the presence of more nicks or gaps in ASF virus than in vaccinia virus INA. llowever, Pickup et ul. (1983) have cloned one vaccinia terminal fragment without any deletion.

The packaging limits of $\lambda$ WES $\lambda \mathrm{B}$ (Feiss ot al., 1977; Williams and Blattner, 1981) indicate a cloning capacity of $2.1-15.1 \mathrm{kbp}$. Therefore, fragments EcoRI-B (14.5 kbp) to $\mathrm{P}(2.2 \mathrm{kbp})$ were expected to be cloned as single inserts in $\lambda$ WES. $\lambda \mathrm{B}$. However, neither frament EcoRI-B nor single fragments shorter than EcoRI-K $(4.8 \mathrm{kbp})$ were found among the recombinants. It is likely that the packaging system used selects against extreme-size inserts.

The clones described in this paper have been used for mapping restriction fragments (Almendral of al., 1984) and viral transeripts (M. I. Salas, J. Rey, J, M. Almendra!, A. Talavera, and E. Vinuela, unpublished results) of ASF virus DNA.

\section{ACKNOWLEIUGMENTS}

We thank Dr. J. Davies and Dr. E. Dominge for providing us information about the crystal violet selection technique and Dr. B. Hohn and 1)r. P. Leder for tr. rolistrains. This investigation has been aided by grants from Comision Asesora para el Iesarrollo de la Investigacion Cientifica y Téenica and Fondo de Investigaciones Sanitarias.

\section{REFERENCES}

Ai.maniral, J. M., Bi,Asco, R., Ley, V., Beloso, A. T'AlaverA, A. and VIÑuel.A, E. (1984). Restriction site map of African swine fever virus IDNA. Virology 133, 258270.
ANDERSoN, S. (1981). Shotgun IDNA sequencing using cloned DNase I-generated fragments. Nucl Acids Res 9, 3015 3027

BakoUnY, B. M, Venkatessan, S, and Moss, B. (1982). Incompletely base-paired flip-flop terminal loops link the two IDNA strands of the vaceinia virus genome into one uninterrupted polynucleotide chain. (ill 28,315:324.

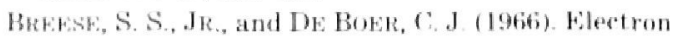
microseope ulsservations of African swine fever virus in tissue culture cells. Virology $28,420-428$

DANIF: S, D) I., and BL.ATTNER, F. R. (1982). Nucleotide sequence of the $Q$ gene and the $Q$ to $S$ intergenic region of bacteriophage lambdat. Virolegn! 117, 81 92

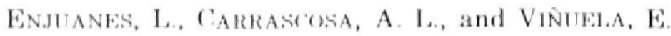
(1976). Isolation and properties of the IDNA of African swine fever (ASF) virus. J. Gen. Virol. 32, $479-492$

Friss, M., Fisher, R. A., CRAYTUN, M. A., and EGoner, C. (1977). Fackaging of the bacteriophage $\lambda$ chromosomes: Fiffect of chromosome length. Virolegul 77, $281-29: 3$

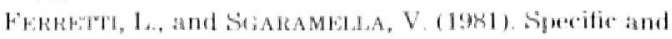
reversible inhibition of the blunt end joining activity of the T4 IDNA ligase. Nurl Arids hes. 9, 36995, 3705.

Gestmin, P', and Berns, K. I. (1974). (haracterization and localization of the naturally occurring crosslinks in vaccinia virus 1 N A . J Mol. Riol 88, 785, 796 .

Grolnstern, M., and Hownthi, D. S. (I976) Colony hybridization: A method for the isolation of cloned IDNAs that contain a specific gene. Prow: Nat. Arad. Sin. 1SA 72, 3961 3965

Hrss, W. R. (1971). African swine fever virus. In"Virology Monographs" (S Gard, C. Hallauer, and K. F. Meyer, als ), Vol 9, pp. 1 :3. Sipringer Verlag. Wien.

Hess, W. R. (1981). African swine fever: A reassess-

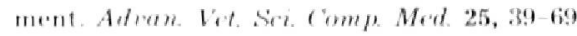

HoHN, B. (1979). In wetre packaging of $\lambda$ and cosmid I)NA. In "Methods in Enzymology" (R. Wu, ed.), Vol. 68, pp. 299-309. Academic Press, New York.

Hold, B, and MurkAy, K. (1977). Packaging recomhinant 1 NA molecules into bacteriophage particles

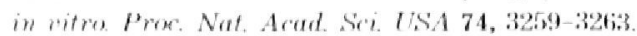

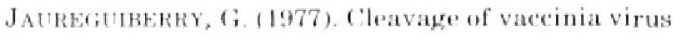
INA by restriction endonuclease Bal I, Eeo RI. Bam HI. Isolation of the natural cross-links. FEBS LAtt.83,111-117.

Lal, (-P., Tuekre, P'. W., Musmansk, J F', and BI.ATTNER, F. R. (1980). Mapping of heavy renes for mouse immunoglobulins $\mathrm{M}$ and I . Seroner 209, 1:48 1353

MANIDEI., M., and IIGGA, A. (1970) Calcium-dependent bacteriophage IDNA infertion. I. Mol. Biol 53, 159 162 .

MANIATIS, T., F'RITSEII, E. F., and SAMBRomk, J. (1982). 
"Molecular Cloning. A Laboratory Manual," Cold Spring Harbor Laboratory, Cold Spring Harbor, N. Y.

Ortin, J., EnJtianes, L., and Viñeila, E. (1979). Crosslinks in African swine fever virus DNA. $J$ Virol. 31, 579-583.

PICKUP, D. J., BAsTIA, D., and Joklik, W. K. (1983). Cloning of the terminal loop of vaccinia virus DNA. Virolomy 124, 215-217.

Proctok, (i. N., and RownI, R. H. (1982). Rosanilins: Indicator dyes for chloramphenicol resistant enterobacteria containing chloramphenicol acetyltransferase. J. Bacteriol. 150, 1375-1382.

SAIN, B., and EkoE1, $\$$. (1981). Bacteriophage purification by gel chromatography. Anal Buochem. 110, $128-130$.

Sogo, J. M., Almendral, J. M., Talavera, A., and VINUELA, E. (1984). Terminal and internal inverted repetitions in African swine fever virus DNA. Viroleng 133, 271-275

Whllams, B. G., and Blattner, F, R. (1981). Bacteriophage lambda vectors for IDNA cloning. In "Genetic Engineering. Princples and Methods" (J. K. Setlow and A. Hollander, eds.), Vol, 2, pp, 201-229. Plenum, New York

WitTek, R., Menna, A., Schumperli, D., STOFFei, S., MULLER, H. K., and WYLER, R. (1977). Hind III and Sst I restriction sites mapped on rabbit poxvirus and vaccinia virus DNA. J. Virol 23, 669-678.

WITTEK, R., and Moss, B. (1980). Tandem repeats within the inverted terminal repetition in vaccinia virus DNA. Cell 21, 277-284.

Yamamoto, K. R., Alberts, B. M., Benzinger, R., Lawhorne, L., and Treirer, G. (1970). Rapid bacteriophage sedimentation in the presence of polyethylene glycol and its applications to large scale purification. Virology 40, 734-744. 